\title{
THE SACRED HEART AND THE CHURCH OF THE POOR
}

\author{
Theresa Sanders
}

In her new book A History of God, Karen Armstrong excoriates piety directed at the Sacred Heart of Jesus: "Concentrating solely on Jesus the man, such a piety is simply a projection which imprisons the Christian in a neurotic egotism," she says $(1993,318)$. Further, she maintains, the Jesus of Sacred Heart devotion is mawkish and sentimental, a far cry from the abrasive Jesus of the Gospels: "In his whining self-pity, he shows the dangers of concentrating on the heart to the exclusion of the head" (317).

Armstrong is not alone in her distaste for adoration of the Sacred Heart. Even a cursory review of literature concerning the devotion reveals a deep-seated antipathy towards it (See, e.g., Gutzwiller 1957). Viewed as maudlin, escapist, and pessimistic, Sacred Heart piety seems the antithesis of Vatican II's clear-eyed, world-affirming optimism. Regarded as excessively individualistic, it seems inimical to concerns for the role of the community in worship and for social and economic justice.

And yet, unlike Armstrong, I do not believe that the symbol can or should be so simply dismissed. Rooted in the early centuries of Christian history, it has played a part in the prayer and piety of numerous saints and mystics; this alone would seem to call for caution in discarding it. More important, however, is the fact that the symbol continues to flourish; in Latin America in particular, devotion to the Sacred Heart remains an important part of Catholic piety.

My thesis in this essay is that the Sacred Heart, reinterpreted, can speak powerfully of the Church's birth from the world's suffering. It can serve as symbol of a new ecclesiology based on a model Jon Sobrino calls "a church of the poor" $(1984,125)$. Perhaps the form that devotion to the Sacred Heart has taken since the seventeenth century, with its litanies and first-Friday Masses, is outmoded; nevertheless, the symbol itself lives. It deserves a new articulation rather than a simple dismissal.

I would like to begin such a rearticulation by exploring three themes that have arisen in connection with the Sacred Heart: the patristic notion of the birth of the Church, the medieval focus on the love of Jesus, and the modern concern for reparation for sin. Next, I will raise questions regard- 
ing these themes, attempting to make clear both why earlier interpretations of the symbol may no longer be adequate and what resources lie in those interpretations for a contemporary approach. Finally, I will offer suggestions toward a liberation theology of the Sacred Heart, a vision of the Church born of suffering.

\section{$I$}

Hugo Rahner notes that the first real devotion to the pierced heart of Jesus appeared only in the early Middle Ages, around the year 1000 C.E. (1957a, 37). And yet, as he points out, the roots of the devotion lie much deeper, in the patristic understanding of John 7:37-38:

On the last and great day of the feast, Jesus stood and cried, saying: If any man thirst, let him come to me, And let him drink, who believes in me. As the Scripture says: Fountains of living water Shall flow from his bosom (H. Rahner 1957b, 30).

Based on this scriptural passage, some ancient commentators understood the Church itself as springing from the side of Jesus. Cyprian declared, "We [the Church, as opposed to the heretics] water the thirsting people of God with the divine permission; we guard the boundaries of the life-giving fountains" $(1964,275)$.

The passage predicting that waters shall flow from Jesus's side is fulfilled later in John's gospel. John 19:34 relates that during Jesus's crucifixion, "one of the soldiers pierced his side with a spear, and at once there came out blood and water." This later passage was, like John 7, taken up by patristic writers, and it too was connected with the birth of the Church.

For example, Tertullian explained that "Adam's sleep shadowed out the death of Christ... that from the wound inflicted on His side might, in like manner (as Eve was formed), be typified the Church, the mother of the living" $(1957,222)$. Augustine elaborated on this theme, interpreting the water and blood as baptism and eucharist: "As for the blood and water which His side...poured forth upon the earth, without a doubt they represent the sacraments by which the Church was formed, as Eve was formed from the side of the sleeping Adam..." $(1959,169)$.

In short, there is a clear sense in early Christian writings that the Church had its birth in the pierced side of Jesus. Spirit, baptism and eucharist flow from Jesus's body, signs of the new creation brought about by his death.

This patristic theme is continued through medieval interpretations of the Sacred Heart. However, in the Middle Ages a new development took 
place. Whereas patristic writers focused on the pierced side as fountain of the Church, medieval mystics turned their attentions to the heart of Jesus as symbol of his love. The connection between side and heart was made evident by one medieval writer: "The iron of the lance has penetrated even to his Heart in order to show us that through his Heart the secrets of his Heart are revealed. Through the bodily opening the tender mercy of our God is seen. .." (Aumann et al. 1982, 59). Numerous medieval mystics described visions in which an exchange of hearts takes place; Jesus places his heart in the believer, and the believer's heart is taken into his body. Medieval writers saw the wound in Jesus's side as an entranceway into the deepest life of God where one could find comfort and refuge and receive mystical knowledge.

By the seventeenth century, the Sacred Heart was interpreted almost exclusively as a symbol of the love of Jesus for humanity. Margaret Mary Alacoque, whose visions of the heart of Jesus engendered a revival of the devotion, prayed, "Place me, O my sweet Saviour, in Thy Sacred Side, and in Thy adorable Heart which is a burning Furnace of pure love, and I shall be in safety" (Croiset 1988, 313). Partly as a response to Enlightenment rationalism, and partly as a reaction to Jansenism, this form of piety became immensely popular.

But at the same time, a new development was taking place. The devotion came to entail a keen sense of the humiliations suffered by Jesus both during his Passion and in the contemporary world, humiliations inflicted by those who refused to show him proper respect. Thus, performance of acts of reparation came to play a key role in Sacred Heart devotions. In a prayer called "Act of Reparation to the Sacred Heart," first published in 1935, believers were called upon to expiate for offenses against Christian modesty in unbecoming dress and behavior, for violations of Sundays and holy days, and for insults against the Pope (Daughters of Saint Paul 1973, 2-3). They were asked to make reparation not only for their own sins, but for the sins of others whose offenses added to the suffering of Jesus.

\section{II}

Such, in brief outline, has been the history of Sacred Heart piety and theology. But as a road toward development of a new interpretation of the symbol, it will be useful to raise some questions regarding the viability of these earlier understandings. Three issues come to mind. First, how appropriate is it to depict the Church as springing full-grown from the side 
of the dying Jesus? Second, why focus on the heart of Jesus rather than on Jesus's life in its entirety? Behind these two questions lies a concern for historical credibility. It is easy for symbols to obscure the complexities of, in this case, the growth of the Church, or the life of Jesus as it was actually lived.

The third question asks whether it is proper to speak of Christians atoning for sins, whether their own or the sins of others. To do so seems to minimize the importance of the cross itself. True, not all Christian theologies have seen the death of Jesus as an act of atonement, but it is impossible to ignore the ones that do. How are believers' acts of reparation related to Jesus's salvific death?

In response to the first question, it must be reaffirmed that during his lifetime, Jesus did not found a Church. Hans Kung dates the Church's birth to the dawn of faith in the resurrection; in his view and in the view of numerous scholars, the Church is most properly a post-Easter phenomenon (1967, 105, 109). Moreover, Kung finds the patristic idea of the Church as the new Eve irrelevant at best: "I confess that this means as little to me as the Devotion to the Sacred Heart ..." $(1971,193 \mathrm{f}$.).

And there is a danger in uncritically attributing the founding of the Church to Jesus. To do so is to obscure the historical complexities of the institution's development. It conveys an illusion of timelessness, suggesting that what is true now has been true in the past and was willed by God to be true for all time.

Why then continue to speak of the birth of the Church from the heart/side of the dying Jesus? Is this not simply an attempt to cloud the enormously complicated process by which the Church evolved? My response is that there is no real conflict here between the historical and the symbolic. The issue is, rather, which symbols most adequately express the deepest truths of history. To speak of the Church's birth from the Sacred Heart is to recognize that Easter has its roots in Good Friday, that proclamations of salvation and grace are only noisy gongs and clanging cymbals unless spoken in compassion not only for but with the suffering. This point is crucial, and it will be taken up later at greater length.

The second question arising from a survey of the Sacred Heart tradition asks why Christians should focus on the heart of Jesus rather than on his life as a whole. As liberation theologies strive to rediscover the socio-economic context in which Jesus spoke, emphasizing his role as a man of and for his times, the use of a symbol such as the Sacred Heart seems regressive. Here again we seem to have a case of the symbolic obscuring the historical. 
And again, my conviction is that it is not inappropriate to use symbols for the person of Jesus. Christianity has done so since its inception. The question is whether or not the heart is a helpful, evocative, challenging symbol. And it is not immediately clear that it is.

Karl Rahner, as part of his well-known work on the nature of symbolism, contends that though many words are used by human beings, some words, as he puts it, "render a single thing translucent to the infinity of all reality" (1961-, 3:295). These words are not merely arbitrary; they are, rather "primal words," words that hold us in their power, words that "bring light to us, not we to them." Rahner lists several: blossom and night, star and day, wind and blood, and breath, and earth, among others (298). Another of these primal words, he adds, is "heart." Not merely a name for a bodily muscle, "heart" means rather the interior center of the human being.

In Rahner's anthropology, the heart is the site of our deepest life. It is the center of our freedom, the original unity of our human existence. And yet, as Rahner knows well, we experience this center more as abyss than axis. Our lives are fragmented; spirit struggles with flesh, and the evil we would not do we do with zeal. Finitude and chance limit our freedom, and the needs of the day pull our minds and bodies in so many directions that we feel that there $i s$ no core, no stillpoint in the turning world. Pausing to look around us, we see not unity but spite, greed and cruelty, not peace but envy and indifference.

Rahner describes this situation with eloquence:

And then our hearts may be so crushed with horror and despair, may feel that their own basic dignity has been dealt a mortal blow to the point where it feels that what little joy and love, faithfulness and blessedness is to be found in this sewer of world-history and human history does not make the sum total of the world and mankind better, but only more terrible still, because there seems to be just enough meaning in the world to make us able to feel the prevailing meaninglessness in all its deathly pain (1961-, 8:237).

But it is precisely this sense of fragmentation, this sense of being poured out in a struggle for joy, love, and faith, that gives credibility to the symbol of the pierced heart. The human heart is not whole. It is wounded, its wounds evidence of our terrible exile from ourselves and our source. And yet, this brokenness is precisely the site of our redemption. Urges Rahner, "And when we experience all this then let us look to the Sacred Heart pierced by the lance and say to ourselves: "The basis of all reality is love'" (237). 
I cite these passages from Rahner because I believe they convey the compelling power of the heart. As I noted above, it is not self-evident that the heart is the most appropriate symbol for the person of Jesus. Romanticized or coated with the sweetness of nostalgia, the heart is a symbol best left to valentines and greeting cards. And yet, understood as our deepest life, as the site of both our love and our despair, the heart can give rise to a theology in which both suffering and redemption find new expression.

This brings us, then, to the third question: what does it mean to speak of human acts of reparation? What role do our sufferings play in our own and in the world's redemption?

Perhaps the place to begin is to ask what role Jesus's suffering played in the world's salvation. What does it mean to speak of an atonement brought about through his death? The question is, of course, enormously complex; more than that, it tends to offend our sensibilities. Why would God demand a cruel and bloody sacrifice in payment for a sin committed long ago by a mythical ancestor? Why should we celebrate the execution of an innocent man?

As a way of exploring this question, I would like to turn now to the work of theologian Norbert Hoffmann. His theology of atonement, I believe, will take us one step further towards an ecclesiology of the Heart.

Hoffmann's work seeks to understand the symbol of the Sacred Heart in the context of a theology of the Trinity. His basic presupposition is that, as he puts it, there is " $a$ 'pro'-structure of Being itself' $(1985,236)$. In other words, the essential form of being is to be "for" another; the essential form of being is love. Hoffmann points to the Trinity as the most fundamental instance of this: the being of the Father, in order to be what it is, expresses itself outward in love for the Son.

Creation is a continuation of the trinitarian relationship. God has no need to create something other than Godself; and yet, in an outpouring of love, God establishes a difference between God and the world as an extension of the Father- Son relationship. Creation is "an establishing of 'sons in the Son," a spilling over of the Father's generosity $(1985,240)$.

Sin, in Hoffmann's understanding, is precisely the refusal of our participation in the Father's relationship to the Son. It is a rejection of our place in the divine economy, and thus the creation of an impossibility: a "place" where God is not.

It is into this place that the Son is sent. The Son, he says, "occupies the 'place of sinners' and allows God to be 'Father' there" (1986, 170). Christ on the cross does not replace sinners but rather em-places them, re-estab- 
lishing them as children of God. Thus Hoffmann understands atonement not in a juridical sense, as a bloody payment for an ancient transgression. Rather, "Atonement is sin changed into the suffering that results from distance from Yahweh" (153). Atonement is sin transformed into the pain of love. It is an enduring of and witnessing to God's absence in the world; it is a suffering of this absence as the most painful evidence of God's desire to be present.

As perfect Son, only Jesus could enact perfect atonement. And yet, says Hoffmann, we also have a share in the work of redemption: "In the atonement of the sons...the Son's mission to sinful flesh is sacramentally implemented to its very last detail" $(1986,184)$. We share in Christ's atonement by sharing in the world's exile from God and transforming that exile into the suffering of love.

Hoffmann clarifies his own understanding of atonement by contrasting it with the theologies of Anselm, Rene Girard, and liberation thinkers, among others (1985, 227-31). In the work of Anselm, he says, Jesus's death does not have any internal connection with sin; Jesus is a counterweight to sin, not the bearer of it. Likewise, for Girard, Jesus is the innocent victim of group psychology; the group chooses a scapegoat, and the group's sins are heaped upon him, but there is no intrinsic relationship between sin and the one who dies for sin.

His critique of liberation theologies runs along much the same lines. Such theologies understand Jesus in solidarity with sinners "not insofar as they are sinners, but insofar as they are social outcasts" $(1985,228)$. Liberation thought, in Hoffmann's view, sees the cross not as atonement for sin but as testimony to God's love despite sin. It neglects, he says, the Pauline theme of salvation through sacrifice.

Hoffmann contends that the sufferings of Jesus must be viewed as expiatory and not merely as vicarious payment for others' sins or as the byproduct of a life dedicated to the oppressed. On the cross, "redemption is accomplished as the bearing of sin itself by the Son"; a miracle of transfiguration takes place whereby sin becomes love $(1985,226)$. This understanding will be crucial to my development of a Sacred Heart theology; and yet, what is unclear in Hoffmann's work is how precisely this death, this form of execution meted out under Roman rule in first-century Judea, is related to God's plan of redemption. Hoffmann calls the cross "the heart of the disobedience of human sin," but there is not enough analysis of why, specifically, execution by cross is an entrance into the deepest recesses of evil (247). Liberation theologies are more helpful on this point. 
In the next section, then, I will explore this issue and attempt to tie it together with several other themes we have touched on so far: the Church's birth from Jesus's wounds; the heart as site of both our love and our despair; and the cross as evidence of humans' refusal of God's creation of them as children. Again, my goal is to develop an ecclesiology in which the Church finds its truest life in its identity with the suffering.

\section{III}

There is a restlessness at the heart of humanity. Glimpsing a fullness of being that lies perpetually beyond our grasp, we move out into the world, constantly seeking more knowledge, more love, more presence. Karl Rahner writes that "it is quite impossible for us to do anything else than search for this unity which consists in the fulness of all things... We do this because we are this act of seeking" (1961-, 8:231).

We are an act of seeking. We hunger for One in whom our desire will find satisfaction, who is unity and truth and presence. Constantly frustrated by our finitude, we limp towards God with the conviction that our very hope of finding rest is reason enough to believe we will.

And yet, it is easy to fall into despair. As Rahner recognized, at times there seems to be just enough meaning in the world to make us aware of "the prevailing meaninglessness in all its deathly pain." We can experience our distance from God as the condition of love, as the space that is desire itself; or, we can refuse our identities as creatures and deny our hope for a "more" than we ourselves are.

But this refusal of God is not a neutral act; it is the perversion of a relationship rather than the absence of one. In turning from God, we feel our distance from God not as indifference but as anguish, privation, exile, and emptiness. Then, trying to satisfy our terrible hungers for love and knowledge, we devour each other in a voracious quest for unimpeded sovereignty.

This, it seems to me, is what Rahner means when he says that the human heart can be empty of love (1961-, 3:327). The heart is the site of our freedom, and in our freedom we choose either for or against God. To choose for God is to accept our distance from God as the condition of our personhood. To turn from God is to pervert freedom into exile, and to construe exile as excuse.

This makes more clear what Hoffmann means when he speaks of atonement as the transformation of sin into the suffering of love, and why it is 
so important to his theology that Jesus be understood not merely as paying for sins, or as dying because of them, but as truly bearing them in himself. Entering into the human condition means entering into the possibility of a loveless heart, into the possibility of hell. The Son's taking this upon himself means that, as Hoffmann writes, "hell itself has already been suffered to death" $(1985,225)$. Henceforth there is no recess of the human heart that cannot be transfigured into love.

This points the way, too, to a theology of atonement through suffering in our own world. As I noted above, since the seventeenth century, acts of reparation have been a key element in Sacred Heart piety. The need for these acts was stressed in the writings of Margaret Mary Alacoque, and their importance grew in the eighteenth century in reaction to the French Revolution. At a time when the Mass was ridiculed and the eucharist desecrated, devotion to the heart of Jesus took on a new urgency.

But it was sometimes unclear precisely what meaning such acts of reparation had. Sacred Heart piety often took as its goal the consolation of Jesus, seeking to jump through time to alleviate the sorrows of Gethsemane and Golgotha. But this form of the devotion easily forgets that Jesus is in fact no longer suffering but has been glorified (K. Rahner 1961-, $3: 347-48$ ). While such devotion may be psychologically powerful, it is theologically problematic.

Moreover, the lists of offenses for which Christians were asked to make reparation sound quaint or even amusing to contemporary ears; after all, in a world as violent and frightening as ours, modesty in dress seems a trivial concern.

But the earth is filled with concerns that are far less trivial. Murder rates rise, and newspapers detail the gruesome acts that compete with each other for our revulsion. Battles and bloodshed are old stories, but technology gives them a new horror. In what Rahner called "this sewer of world history and human history," the refusal of our identity as children of God is no mere theoretical choice; it manifests itself in the sufferings of others.

This is the point where, it seems to me, Hoffmann's theology of atonement can be complemented by the work of liberation theologians. Hoffmann does not make clear exactly what conditions led up to the crucifixion of Jesus: that is, what social, economic, and political significance the crucifixion had. But in the work of Jon Sobrino we find an explicit connection between the sins of the world and the death of Jesus: "The fate of Jesus can be explained historically only in light of his solidarity with the poor masses and his energetic defense of them and attacks on their oppressors" $(1984,49)$. 
In other words, it was not just any death, even any death suffered by Jesus, that was an act of atonement. Jesus suffered by bearing sin, but sin always takes a concrete form. Writes Sobrino, "He...denounced every form of oppression that was practiced by the economically strong, the intellectuals, the religious leaders, and the political leaders" $(1984,238)$. This denunciation of oppression led to his execution.

What does it mean to say, then, that we continue the atoning work of Jesus? If Hoffmann is correct, it means that we transform sin into love. And if we add Sobrino's insights, we see that this is enacted by suffering the sins of the world, sins that manifest themselves as injustice, violence, and exploitation.

It is the poor who suffer the most from these sins. And thus the Church, if it to truly continue Jesus's work, must be a Church of the poor. Sobrino makes a distinction between a Church for the poor and a Church of or from the poor. A Church for the poor, he explains, is one that shows concern for the poor. But this is not enough; it merely turns the poor into another problem to be solved by those who are in power.

In contrast, he describes a Church of the poor. Such a Church has its basis in "the majority of human beings, who both individually and collectively constitute the real poor not only because of their natural condition of poverty, but also because of their historical condition of impoverishment by others" $(1984,135)$. They are the ones who suffer for the sins of others. Because of this, they are those who can transform the distance of sin into the suffering of love; in other words, they are those who can enact atonement.

This is not to say that the role of the Church, much less the role of the poor, is simply to endure evil in quiet suffering. Enacting atonement does not mean simply accepting whatever atrocities the world inflicts, gazing heaven-ward in resolute faith. On the contrary, the suffering of Jesus came about precisely because of his vigorous denunciation of injustice, arrogance, and hypocrisy. Love requires action; Christian love requires that one follow Jesus in preaching, teaching, challenging, and healing.

And thus we arrive at an ecclesiology of the Sacred Heart. The body of Jesus was beaten, broken, killed, and afterwards mutilated. But it was precisely the evidence of this torture (and not merely the vision of the resurrected Christ) that prompted Thomas to exclaim, "My Lord and my God!" (John 20:28). To say that the Church is born from the Sacred Heart, the heart that was pierced and left gaping, is to say that the Church is for and of the suffering. 
Perhaps it will be helpful now to review the connections I have attempted to make between the Sacred Heart and an ecclesiology of the poor.

Since the seventeenth century, there has been a strong emphasis on the need for reparation in Sacred Heart theology. Taking up this tradition, I have tried to refocus it, turning attention from sins against ritual to sins of violence and exploitation against the poor. To make reparation for $\sin , \mathbf{I}$ have suggested, requires suffering sin in love, suffering it to death, if need be, and thereby transfiguring it. Such suffering is not simply a passive response, but requires action rooted in hope.

Since the Middle Ages, the Sacred Heart has functioned as a symbol of love. But using Rahner's insights, I have argued that the human heart is a place of love only when freedom makes it so. Broken and longing for God, the heart can twist its own desires into a rapacious devouring of others. Only a freely chosen option for love can make the heart a site of steadfast, hopeful desire for fulfillment.

Finally, I have attempted to recover the patristic theme of the Church's birth from Jesus's side. Patristic writers interpreted John's description of waters that flowed from Jesus's body in light of the Genesis creation story; thus, the Church was depicted as the new Eve who gives life to the world through the sacraments. I have adopted the patristic account of the Church's birth but emphasized instead the significance of Jesus's suffering. That is, the Church's role is bearing, like Jesus, the sins of the world in a resolute proclamation of God's love. To do so is to be where the poor are, is to be the poor.

Georgetown University

\section{Bibliography}

Armstrong, Karen. 1993. A History of God. New York: Alfred A. Knopf.

Augustine. 1959. For the Recent Converts. Translated by Mary Sarah Muldowney. The Fathers of the Church v. 38. New York: Fathers of the Church, Inc.

Aumann, Jordan, et al. 1982. Devotion to the Heart of Jesus. Rome: Institute of Spirituality of the Pontifical University of Saint Thomas Aquinas.

Croiset, John. 1988. The Devotion to the Sacred Heart of Jesus. 2d ed. Translated by Patrick O'Connell. Rockford, Illinois: TAN Books and Publishers.

Cyprian. 1964. Letters. Translated by Rose Bernard Donna. Fathers of the Church v. 51. Washington, D.C.: Catholic University of America Press. 
Daughters of Saint Paul. Little Treasury of the Sacred Heart. [1935, 1941] 1973. Boston: Daughters of Saint Paul.

Gutzwiller, Richard. 1957. The Opposition. In Heart of the Saviour. Edited by Josef Stierli. Translated by Paul Andrews. New York: Herder and Herder.

Hoffmann, Norbert. 1985. Atonement and the Ontological Coherence Between the Trinity and the Cross. In Towards a Civilization of Love. Edited by the International Institute of the Heart of Jesus. San Francisco: Ignatius Press.

1986. Atonement and the Spirituality of the Sacred Heart. In Faith in Christ and the Worship of Christ. Edited by Leo Scheffczyk. Translated by Graham Harrison. San Francisco: Ignatius Press.

Kung, Hans. 1967. The Church. New York: Image Books.

1971. Die Kirche des Evangeliums. In Diskussion um Hans Kung "Die Kirche". Freiburg-Basel-Vienna. Quoted in Norbert Hoffmann, Atonement and the Spirituality of the Sacred Heart. In Faith in Christ and the Worship of Christ. Edited by Leo Scheffczyk. Translated by Graham Harrison (San Francisco: Ignatius Press, 1986).

Rahner, Hugo. 1957. The Beginnings of the Devotion in Patristic Times. In Heart of the Saviour. Edited by Josef Stierli. Translated by Paul Andrews. New York: Herder and Herder.

1957. On the Biblical Basis of the Devotion. In Heart of the Saviour.

Edited by Josef Stierli. Translated by Paul Andrews. New York: Herder and Herder.

Rahner, Karl. 1961-. Theological Investigations. New York: Crossroad.

Sobrino, Jon. 1984. The True Church and the Poor. Translated by Matthew J. O'Connell. Maryknoll, New York: Orbis Books.

Tertullian. 1957. A Treatise on the Soul. Ante-Nicene Fathers v. 3. Grand Rapids, Michigan: Wm. B. Eerdmans. 